\title{
DNA repair gene variants are associated with an increased risk of myelodysplastic syndromes in a Czech population
}

\author{
Monika Belickova ${ }^{1,2^{*}}$, Michaela Dostalova Merkerova ${ }^{1}$, Eliska Stara ${ }^{1}$, Jitka Vesela', Dana Sponerova ${ }^{1}$, \\ Dana Mikulenkova', Radim Brdicka', Radana Neuwirtova ${ }^{2,3}$, Anna Jonasova ${ }^{2,3}$ and Jaroslav Cermak ${ }^{1,2}$
}

\begin{abstract}
Background: Interactions between genetic variants and risk factors in myelodysplastic syndromes are poorly understood. In this case-control study, we analyzed 1421 single nucleotide polymorphisms in 408 genes involved in cancer-related pathways in 198 patients and 292 controls.

Methods: The Illumina SNP Cancer Panel was used for genotyping of samples. The chi-squared, p-values, odds ratios and upper and lower limits of the 95\% confidence interval were calculated for all the SNPs that passed the quality control filtering.

Results: Gene-based analysis showed nine candidate single nucleotide polymorphisms significantly associated with the disease susceptibility (q-value $<0.05$ ). Four of these polymorphisms were located in oxidative damage/DNA repair genes (LIG1, RAD52, MSH3 and GPX3), which may play important roles in the pathobiology of myelodysplastic syndromes. Two of nine candidate polymorphisms were located in transmembrane transporters ( $A B C B 1$ and $S L(4 A 2)$, contributing to individual variability in drug responses and patient prognoses. Moreover, the variations in the ROS1 and STK6 genes were associated with the overall survival of patients.
\end{abstract}

Conclusions: Our association study identified genetic variants in Czech population that may serve as potential markers for myelodysplastic syndromes.

Keywords: Myelodysplastic syndromes, SNP, DNA repair, Association study

\section{Introduction}

Myelodysplastic syndromes (MDS) are heterogeneous hematopoietic diseases characterized by ineffective hematopoiesis that frequently transform into acute leukemia. Because genetic background is thought to influence the risk of developing MDS, several casecontrol studies have investigated the relationships between specific genetic polymorphisms and the risk of MDS [1-5]. For example, the GSTP1 (glutathione S-transferase pi 1) - 105Val allele has been reported to be associated with an increased risk of MDS [3]. In addition, an association between a polymorphism

\footnotetext{
* Correspondence: monika.belickova@uhkt.cz

'Institute of Hematology and Blood Transfusion, U Nemocnice 1, Prague, Czech Republic

${ }^{2}$ First Faculty of Medicine, Charles University, Prague, Czech Republic Full list of author information is available at the end of the article
}

in the erythropoietin gene and MDS has been described [4]. Despite these studies, the genetic risk factors for MDS remain poorly understood. In this case-control study, we examined single nucleotide polymorphisms (SNPs) in genes associated with an increased risk of MDS in a Czech population.

\section{Material and methods}

\section{Study population}

Peripheral blood or bone marrow samples were obtained from Caucasian Czech patients with de novo MDS or acute myeloid leukemia with myelodysplasia-related changes $(n=198)$ and from Caucasian Czech age and gender matched controls $(n=292)$ in the Institute of Hematology and Blood Transfusion and the First Department of Internal Medicine, General Faculty Hospital, Prague. Samples were obtained during routine clinical assessment from

\section{Ciomed Central}


2003 to 2010. Only patients with de novo MDS without evidence of previous exposure to radiation or chemotherapy were enrolled in the study. The MDS diagnoses were based on the standard diagnostic criteria of the World Health Organization [6]. WHO classification and therapy of patients is summarized in Table 1. All the subjects provided informed consent, and the study was approved by the Local Ethics Committee. The median age of the patients was 63 years (range: 18-89 years), and the median age of the controls was 61 years (range: 19-98 years). Patient group consisted of $69.7 \%$ women and control group from $65.4 \%$ women.

\section{Genotyping}

We analyzed 1421 SNPs in 408 genes involved in cancerrelated pathways using the Illumina GoldenGate Assay (Illumina Inc., USA). The Cancer SNP Panel contents over 400 genes involved in the etiology of various types of cancer selected from the National Cancer Institute's Cancer Genome Anatomy Project SNP500Cancer Database. This panel contains more than 3 SNPs, on average, for each gene represented. The list of all tested genes is accessible in Additional file 1: Table S1. The assay was performed according to the manufacturer's protocol for the Illumina GoldenGate Assay.

\section{Statistical analysis}

The raw data were imported into GenomeStudio V2009.2 (Illumina) for SNP clustering and the generation of genotype calls. The calculations were performed in the statistical programming language $\mathrm{R}$ (version 2.12.0; www. r-project.org). We excluded 35 samples with an overall call rate $<90 \%$ and 15 SNPs with a call rate $<80 \%$. In addition, the deviation of the genotype proportions from HardyWeinberg equilibrium (HWE) was assessed in the controls, and 22 SNPs with p-values $<3.56-05$ (Bonferroni correction for multiple testing: 0.05/1406) showed significant deviations from HWE and were thus removed. This resulted in the inclusion of a total of 1384 SNPs and 455 samples for our analysis. The chi-squared, p-values, odds ratios (ORs) and upper and lower limits of the 95\% confidence interval $(\mathrm{CI})$ of the OR were calculated for all the SNPs that passed the QC filtering. Applying the false discovery rate (FDR) for multiple testing at a $5 \%$ significance level according to the Benjamini-Hochberg was supposed to show significant association of the SNP with the phenotype. We identified 9 genes with an adjusted q-value lower than 0.05. Survival plots for the MDS cases were generated using the Kaplan-Meier method, and the differences between the genotypes were assessed using the log-rank test.

\section{Validation of SNPs results}

The results of SNPs status of three selected genes (LIG1, RAD52, GPX3) were validated using SNPsTaqMan $^{\circledR}$ Assays (Life Technologies, USA). Paired CD3 cells and CD14 cells were used to distinguish germline or somatic polymorphisms. We compared the SNP status between CD3 T lymphocytes and CD14 monocytes in LIG1, RAD52 and GPX3 genes in 68 patients.

\section{Results and discussion}

A gene-based analysis identified nine candidate SNPs that were significantly associated $(\mathrm{q}$-value $<0.05)$ with disease

Table 1 Characteristics of patients

\begin{tabular}{cccc}
\hline & WHO classification & & Cytogenetics, normal/abnormal \\
\hline MDS del(5q) & $\mathbf{n} / \%$ & Blast (\%) & $0 / 24$ \\
\hline RCUD & $24(12.1)$ & 2.8 & $10 / 2$ \\
\hline RARS & $14(7.1)$ & 1.1 & $5 / 4$ \\
\hline RCMD & $12(6.1)$ & 1.4 & $36 / 17$ \\
\hline RAEB-1 & $59(29.8)$ & 1.6 & $11 / 10$ \\
\hline RAEB-2 & $26(13.1)$ & 4.4 & $10 / 9$ \\
\hline MDS-U & $25(12.6)$ & 12.5 & $3 / 0$ \\
\hline MDS/MPS & $3(1.5)$ & 2.0 & $12 / 7$ \\
\hline AML with MRC & $23(11.6)$ & 8.3 & $4 / 6$ \\
\hline Age(yr) & $12(6.1)$ & 28.3 & \\
\hline Median/range & & & \\
\hline Sex & $63(18-89)$ & & \\
\hline Male n/\% & $60(30.3)$ & & \\
\hline Female n/\% & $138(69.7)$ & & \\
\hline
\end{tabular}

MDS del(5q): MDS associated with isolated del(5q); RCUD: Refractory cytopenias with unilineage dysplasia; RARS: Refractory anemia with ring sideroblasts; RCMD: Refractory cytopenias with multilineage dysplasia; RAEB-1: Refractory anemia with excess blasts, type 1; RAEB-2: Refractory anemia with excess blasts, type 2; MDS-U: MDS, unclassifiable; MDS/MPS: MDS and myeloproliferative syndromes; AML with MRC: Acute myeloid leukemia with myelodysplasia - related changes. 
susceptibility. The results of the association analysis are presented in Table 2. The OR of the genes with significant heterozygous and homozygous variants is listed in Table 3. Furthermore, we examined the relationships between the genotyping results and the clinical data. A Kaplan-Maier analysis revealed that alleles in the c-ros oncogene 1 (ROS1) gene $(\mathrm{p}=0.001)$ and aurora kinase A (STK6/ AURKA) gene $(\mathrm{p}=0.0002)$ were independent prognostic factors for survival in our patient cohort (Figure 1). The other genetic polymorphisms identified in this study did not play any prognostic role (LIG1: $\mathrm{p}=0.11$; $A B C B 1: \mathrm{p}=0.08 ;$ SLC4A2: $\mathrm{p}=0.48 ;$ RAD52: $\mathrm{p}=0.41 ;$ $P G R: \mathrm{p}=0.99 ; M S H 3: \mathrm{p}=\mathrm{NA} ; G P X 3: \mathrm{p}=0.64)$.

The most significant association was observed for the rs13240966 SNP $\left(p=7.00 \mathrm{E}^{-11}\right)$, which is located in the solute carrier family 4 , anion exchanger, member 2 (SLC4A2) gene. SLC4A2 is a widely distributed plasma membrane anion exchange protein involved in the regulation of intracellular $\mathrm{pH}$ through the exchange of intracellular bicarbonate for extracellular $\mathrm{Cl}^{-}$. We detected an association between the homozygous $\mathrm{C} / \mathrm{C}$ genotype and MDS (OR 4.86; 95\% CI 2.74-8.62). This SNP was previously associated with bladder cancer in work by Andrew et al. [7]. We also found a significant association between MDS and a polymorphism in a gene that encodes another transmembrane protein, which belongs to the $A B C$ (ATP-binding cassette) protein transporter family. $A B C$ sub-family $\mathrm{B}$ member $1(A B C B 1)$ is responsible for decreased drug accumulation in multidrugresistant cells and often mediates the development of resistance to anticancer drugs. In our patient cohort, the heterozygous $\mathrm{A} / \mathrm{G}$ genotype of $A B C B 1$ was associated with MDS susceptibility (OR 3.79; 95\% CI 2.30-6.24). The specific genotype of $A B C B 1$ has also been proposed to influence the risk of acute lymphoblastic leukemia (ALL), and other $A B C B 1$ variants may be linked to poor ALL prognoses [8].

The gene that encodes ligase 1 (LIG1) was represented in the assay by the marker rs20580. We detected a relationship between the homozygous A/A genotype of this LIG1 SNP and MDS ( $\mathrm{p}=1.65 \mathrm{E}^{-06}$; OR 3.28; 95\% CI 1.776.06). LIG1 plays roles in nucleotide excision repair and in the long-patch base-excision repair pathway. An association of this genetic variant with lung cancer was previously reported by Lee et al. [9]. We found significant associations between MDS and of two other polymorphisms in genes related to DNA repair. One of these SNPs was the rs11226 SNP $\left(\mathrm{p}=1.70 \mathrm{E}^{-04}\right)$ in the RAD52 gene, which is involved in DNA double-strand break repair and homologous recombination. The second polymorphism was $\operatorname{rs} 3797896\left(p=2.16 \mathrm{E}^{-04}\right)$, which is located in the MSH3 gene, a component of the post-replicative DNA mismatch repair system. In addition, genetic variants in several other genes involved in DNA repair were significantly associated with MDS $(\mathrm{p}<0.01)$, including rs2238335 in the BLM gene (Bloom syndrome, RecQ-helicase-like), rs2308327 in MGMT (O-6-methylguanineDNA methyltransferase), rs4149963 in EXO 1 (exonuclease 1) and rs7607076 in MSH2 (mutS homolog-2, colon cancer, nonpolyposis type-1). Previous work has demonstrated that polymorphisms in DNA damage-response genes and DNA repair genes influence DNA repair capacity $[10,11]$. DNA damage caused by ineffective detoxification or defects in DNA repair can lead to chromosomal

Table 2 SNPs showing significant genotypic associations with myelodysplastic syndromes

\begin{tabular}{|c|c|c|c|c|c|c|c|c|c|c|c|}
\hline Gene & Name & $\begin{array}{l}\text { Gene } \\
\text { location }\end{array}$ & $\begin{array}{l}\text { dbSNPs } \\
\text { reference } \\
\text { number }\end{array}$ & $\begin{array}{l}\text { Gene } \\
\text { region }\end{array}$ & Genotype & $\begin{array}{l}\text { MAF } \\
\text { database }\end{array}$ & $\begin{array}{l}\text { MAF } \\
\text { controls }\end{array}$ & $\begin{array}{l}\text { MAF } \\
\text { patients }\end{array}$ & OR & $\begin{array}{l}95 \% \\
\text { confidence } \\
\text { interval }\end{array}$ & P Value \\
\hline SLC4A2 & $\begin{array}{l}\text { solute carrier family } 4 \text {, } \\
\text { anion exchanger, } \\
\text { member } 2\end{array}$ & $7 q 36.1$ & rs13240966 & intron & $C / G$ & 0.227 & 0.4829 & 0.7110 & 2.63 & $1.94-3.63$ & 7.00E-11 \\
\hline ABCB1 & $\begin{array}{l}\text { ATP-binding cassette, } \\
\text { sub-family B (MDR/ } \\
\text { TAP), member } 1\end{array}$ & $7 q 21.12$ & rs2235074 & intron & $\mathrm{A} / \mathrm{G}$ & 0.031 & 0.0575 & 0.1569 & 3.05 & $1.88-4.97$ & 8.65E-07 \\
\hline LIG1 & $\begin{array}{l}\text { ligase I, DNA, ATP- } \\
\text { dependent }\end{array}$ & $19 q 13.2-q 13.3$ & rs 20580 & coding & $\mathrm{A} / \mathrm{C}$ & 0.513 & 0.2216 & 0.3665 & 2.03 & $1.50-2.75$ & $1.65 \mathrm{E}-06$ \\
\hline ROS1 & $\begin{array}{l}\text { c-ros oncogene } 1 \text {, } \\
\text { receptor tyrosine } \\
\text { kinase }\end{array}$ & $6 q 22$ & rs574664 & intron & $\mathrm{T} / \mathrm{A}$ & 0.145 & 0.1432 & 0.2593 & 2.10 & $1.48-3.00$ & $1.24 \mathrm{E}-05$ \\
\hline PGR & progesterone receptor & $11 q 22-q 23$ & rs1042838 & coding & $\mathrm{T} / \mathrm{G}$ & 0.199 & 0.1601 & 0.2804 & 2.05 & $1.46-2.87$ & 1.46E-05 \\
\hline STK6 & aurora kinase $\mathrm{A}$ & $20 q 13$ & rs732417 & 5UTR & $\mathrm{C} / \mathrm{G}$ & 0.083 & 0.1051 & 0.1995 & 2.12 & $1.43-3.16$ & 7.76E-05 \\
\hline GPX3 & $\begin{array}{l}\text { glutathione } \\
\text { peroxidase } 3\end{array}$ & $5 q 23$ & rs8177426 & intron & $A / G$ & 0.217 & 0.2288 & 0.3567 & 1.87 & $1.37-2.55$ & 4.26E-05 \\
\hline RAD52 & RAD52 homolog & $12 p 13-p 12.2$ & rs11226 & 3UTR & $\mathrm{T} / \mathrm{C}$ & 0.224 & 0.2308 & 0.3509 & 1.80 & $1.31-2.48$ & $1.70 \mathrm{E}-04$ \\
\hline MSH3 & mutS homolog 3 & $5 q 11-q 12$ & rs3797896 & intron & $\mathrm{G} / \mathrm{C}$ & 0.066 & 0.0627 & 0.0131 & 0.20 & $0.07-0.54$ & 2.16E-04 \\
\hline
\end{tabular}


Table 3 Association between individual SNPs and MDS

\begin{tabular}{|c|c|c|c|c|c|}
\hline SNP & Genotype & $\begin{array}{l}\text { Controls } \\
\mathrm{N}(\%)\end{array}$ & $\begin{array}{l}\text { Cases } \\
\mathrm{N}(\%) \\
\end{array}$ & $\begin{array}{l}\text { OR } \\
(95 \% \mathrm{Cl})\end{array}$ & p-Values \\
\hline \multirow[t]{5}{*}{ rs13240966 } & $S L C 4 A 2$ & 235 & 173 & & \\
\hline & GG & 72 (30.64) & $\begin{array}{l}22 \\
(12.72)\end{array}$ & 1.0 (Ref) & \\
\hline & $\mathrm{CC}$ & $64(27.23)$ & $\begin{array}{l}95 \\
(57.91)\end{array}$ & $\begin{array}{l}\mathbf{4 . 8 6} \\
(2.74-8.62)\end{array}$ & $<0.0001$ \\
\hline & CG & 99 (42.13) & $\begin{array}{l}56 \\
(32.37) \\
\end{array}$ & $\begin{array}{l}1.85 \\
(1.04-3.30)\end{array}$ & 0.04 \\
\hline & $\mathrm{CC}+\mathrm{CG}$ & $\begin{array}{l}163 \\
(69.36)\end{array}$ & $\begin{array}{l}151 \\
(87.28)\end{array}$ & $\begin{array}{l}\mathbf{3 . 0 3} \\
(1.79-5.13)\end{array}$ & $<0.0001$ \\
\hline \multirow[t]{5}{*}{ rs2235074 } & $A B C B 1$ & 261 & 188 & & \\
\hline & GG & $\begin{array}{l}232 \\
(88.55)\end{array}$ & $\begin{array}{l}129 \\
(68.62)\end{array}$ & 1.0 (Ref) & \\
\hline & AA & $1(0.38)$ & $0(0.00)$ & NA & \\
\hline & AG & 28 (10.69) & $\begin{array}{l}59 \\
(31.38)\end{array}$ & $\begin{array}{l}\mathbf{3 . 7 9} \\
(2.30-6.24)\end{array}$ & $<0.0001$ \\
\hline & $A A+A G$ & $29(11.07)$ & $\begin{array}{l}59 \\
(31.38)\end{array}$ & $\begin{array}{l}3.66 \\
(2.23-6.00)\end{array}$ & $<0.0001$ \\
\hline \multirow[t]{5}{*}{ rs 20580} & LIG1 & 264 & 191 & & \\
\hline & CC & $\begin{array}{l}167 \\
(63.26) \\
\end{array}$ & $\begin{array}{l}84 \\
(43.98) \\
\end{array}$ & 1.0 (Ref) & \\
\hline & $A A$ & $20(7.58)$ & $\begin{array}{l}33 \\
(17.28) \\
\end{array}$ & $\begin{array}{l}3.28 \\
(1.77-6.06) \\
\end{array}$ & $<0.0001$ \\
\hline & $A C$ & 77 (29.17) & $\begin{array}{l}74 \\
(38.74) \\
\end{array}$ & $\begin{array}{l}\mathbf{1 . 9 1} \\
(1.26-2.89) \\
\end{array}$ & 0.002 \\
\hline & $A A+A C$ & $97(36.74)$ & $\begin{array}{l}110 \\
(57.59) \\
\end{array}$ & $\begin{array}{l}2.25 \\
(1.54-3.29) \\
\end{array}$ & $<0.0001$ \\
\hline \multirow[t]{5}{*}{ rs574664 } & ROS1 & 262 & 189 & & \\
\hline & $\mathrm{TT}$ & $\begin{array}{l}191 \\
(72.90) \\
\end{array}$ & $\begin{array}{l}95 \\
(50.26) \\
\end{array}$ & 1.0 (Ref) & \\
\hline & AA & $4(1.53)$ & $4(2.12)$ & $\begin{array}{l}2.01 \\
(0.49-8.22) \\
\end{array}$ & 0.32 \\
\hline & TA & $67(25.57)$ & $\begin{array}{l}90 \\
(47.62)\end{array}$ & $\begin{array}{l}\mathbf{2 . 7 0} \\
(1.81-4.03)\end{array}$ & $<0.0001$ \\
\hline & $A A+T A$ & $71(27.10)$ & $\begin{array}{l}94 \\
(49.74)\end{array}$ & $\begin{array}{l}\mathbf{2 . 6 6} \\
(1.79-3.95)\end{array}$ & $<0.0001$ \\
\hline \multirow[t]{5}{*}{ rs732417 } & STK6 & 257 & 188 & & \\
\hline & GG & $\begin{array}{l}203 \\
(78.99)\end{array}$ & $\begin{array}{l}113 \\
(60.11) \\
\end{array}$ & 1.0 (Ref) & \\
\hline & $\mathrm{CC}$ & $0(0.00)$ & $2(1.06)$ & NA & \\
\hline & CG & $54(21.01)$ & $\begin{array}{l}73 \\
(38.83)\end{array}$ & $\begin{array}{l}\mathbf{2 . 4 3} \\
(1.60-3.70)\end{array}$ & $<0.0001$ \\
\hline & $\mathrm{CC}+\mathrm{CG}$ & $54(21.01)$ & $\begin{array}{l}75 \\
(39.89) \\
\end{array}$ & $\begin{array}{l}\mathbf{2 . 5 0} \\
(1.61-3.88)\end{array}$ & $<0.0001$ \\
\hline \multirow[t]{5}{*}{ rs1042838 } & $P G R$ & 253 & 189 & & \\
\hline & GG & $\begin{array}{l}174 \\
(68.77) \\
\end{array}$ & $\begin{array}{l}86 \\
(45.50) \\
\end{array}$ & 1.0 (Ref) & \\
\hline & TT & $2(0.79)$ & $3(1.59)$ & $\begin{array}{l}3.04(0.40- \\
26.49)\end{array}$ & 0.34 \\
\hline & TG & 77 (30.43) & $\begin{array}{l}100 \\
(52.91)\end{array}$ & $\begin{array}{l}\mathbf{2 . 6 3} \\
(1.74-3.97)\end{array}$ & $<0.0001$ \\
\hline & $\mathrm{TT}+\mathrm{TG}$ & 79 (31.23) & $\begin{array}{l}103 \\
(54.50)\end{array}$ & $\begin{array}{l}\mathbf{2 . 6 4} \\
(1.75-3.98)\end{array}$ & $<0.0001$ \\
\hline rs8177426 & GPX3 & 260 & 171 & & \\
\hline
\end{tabular}

Table 3 Association between individual SNPs and MDS (Continued)

\begin{tabular}{|c|c|c|c|c|c|}
\hline & GG & $\begin{array}{l}155 \\
(59.62)\end{array}$ & $\begin{array}{l}82 \\
(47.95)\end{array}$ & 1.0 (Ref) & \\
\hline & AA & $14(5.38)$ & $\begin{array}{l}33 \\
(19.30)\end{array}$ & $\begin{array}{l}\mathbf{4 . 4 6} \\
(2.16-9.32)\end{array}$ & $<0.0001$ \\
\hline & AG & $91(35.00)$ & $\begin{array}{l}56 \\
(32.75)\end{array}$ & $\begin{array}{l}1.16(0.74- \\
1.82)\end{array}$ & 0.51 \\
\hline & $A A+A G$ & $\begin{array}{l}105 \\
(40.38)\end{array}$ & $\begin{array}{l}92 \\
(53.80)\end{array}$ & $\begin{array}{l}1.66 \\
(1.10-2.47)\end{array}$ & 0.01 \\
\hline \multirow[t]{5}{*}{ rs11226 } & RAD52 & 234 & 171 & & \\
\hline & $\mathrm{CC}$ & $(61.11)$ & $\begin{array}{l}83 \\
(48.54)\end{array}$ & 1.0 (Ref) & \\
\hline & TT & $17(7.26)$ & $\begin{array}{l}32 \\
(18.71)\end{array}$ & $\begin{array}{l}3.24 \\
(1.62-6.53)\end{array}$ & 0.0002 \\
\hline & $\mathrm{TC}$ & $74(31.62)$ & $\begin{array}{l}56 \\
(32.75)\end{array}$ & $\begin{array}{l}1.30(0.82- \\
2.07)\end{array}$ & 0.26 \\
\hline & $\mathrm{TT}+\mathrm{TC}$ & 91 (38.88) & $\begin{array}{l}90 \\
(52.63)\end{array}$ & $\begin{array}{l}1.70(1.15- \\
2.54)\end{array}$ & 0.01 \\
\hline \multirow[t]{5}{*}{ rs3797896 } & MSH3 & 262 & 191 & & \\
\hline & CC & $\begin{array}{l}232 \\
(88.21)\end{array}$ & $\begin{array}{l}186 \\
(97.38)\end{array}$ & 1.0 (Ref) & \\
\hline & GG & $3(1.14)$ & $0(0.00)$ & NA & \\
\hline & GC & $27(10.27)$ & $5(2.62)$ & $\begin{array}{l}\mathbf{0 . 2 3} \\
(0.09-0.61)\end{array}$ & 0.001 \\
\hline & $\mathrm{GG}+\mathrm{GC}$ & $30(11.40)$ & $5(2.62)$ & $\begin{array}{l}\mathbf{0 . 2 1} \\
(0.08-0.55)\end{array}$ & 0.001 \\
\hline
\end{tabular}

instability, which can be associated with tumor formation or progression. Thus, genetic variants in DNA repair may modify the risk of MDS.

We also identified a significant association $\left(\mathrm{p}=4.26 \mathrm{E}^{-05}\right)$ between MDS and the rs8177426 SNP in glutathione peroxidase 3 (GPX3), with an OR of 4.46 (95\% CI 2.16-9.32) for the homozygous A/A genotype. GPX3 protects cells and enzymes from oxidative damage by catalyzing the reduction of hydrogen peroxide, lipid peroxides and organic hydroperoxide by glutathione. In our previous study, we detected a 1.6-fold decrease in GPX3 gene expression in MDS patients [12], suggesting that altered gene expression may be an impact of genetic variants.

Another SNP that was significantly associated with MDS in the present work was $\operatorname{rs732417}\left(\mathrm{p}=7.76 \mathrm{E}^{-05}\right)$, which is located in the STK6/AURKA gene. AURKA, a serine/threonine kinase, regulates cell cycle checkpoints and maintains genomic integrity. We detected an association between the heterozygous $\mathrm{C} / \mathrm{G}$ genotype and the risk of MDS (OR 2.43, 95\% CI 1.60-3.70). Allelic variations in AURKA have been associated with alterations in its expression level and an increased risk of multiple cancers $[13,14]$. Andrew et al. [7] demonstrated that subjects with certain AURKA polymorphisms were significantly more susceptible to bladder cancer. It is noteworthy that the individuals with the homozygous G/G genotype displayed poorer survival than did the patients with other genotypes. 


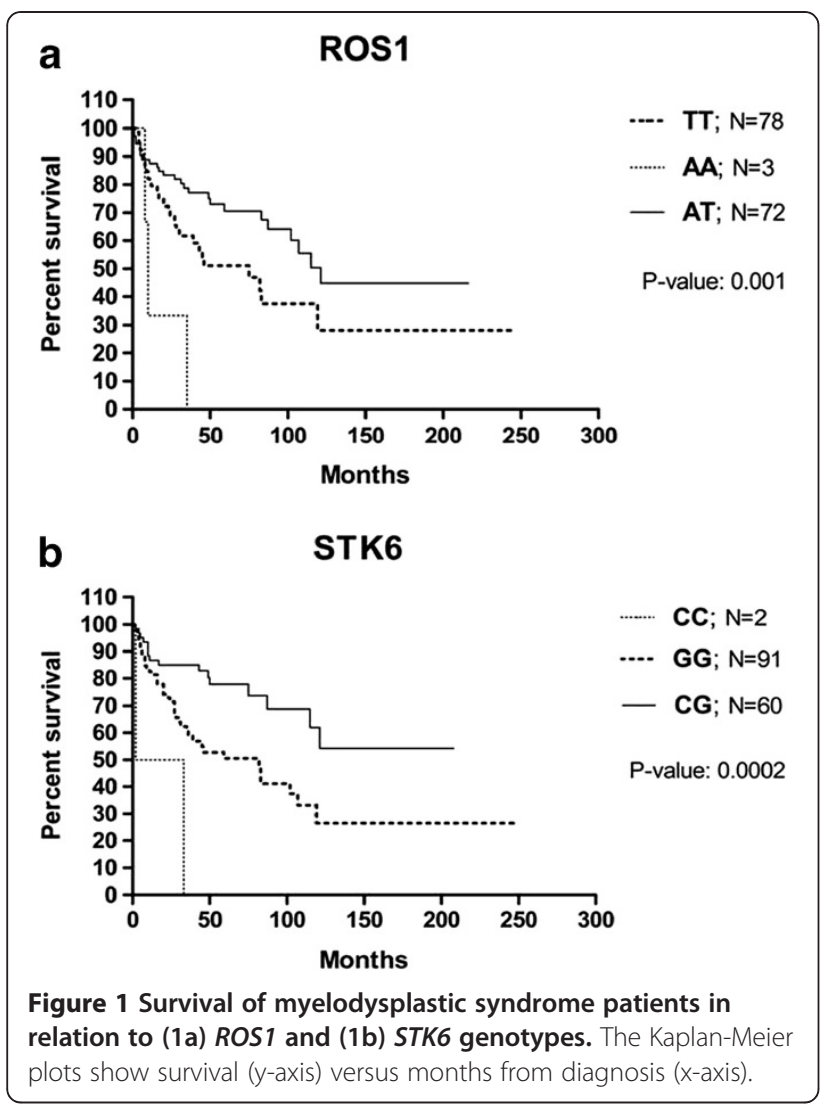

The gene encoding the progesterone receptor (PGR) was represented by rs1042838 $\left(\mathrm{p}=1.46 \mathrm{E}^{-05}\right)$ and was also found to be associated with MDS. Steroid hormones and their receptors are involved in the regulation of gene expression and can affect cellular proliferation and differentiation in target tissues. PGRs signal by binding to other proteins, mainly transcription factors such as NFKB1, $A P-1$ or STAT, which are deregulated in MDS $[15,16]$.

The genotyping analysis also detected an association between rs574664 $\left(\mathrm{p}=1.24 \mathrm{E}^{-05}\right)$ in ROS1 gene and susceptibility to MDS. ROS1 encodes a proto-oncogene with tyrosine kinase activity that may function as a growth or differentiation factor receptor. Specifically, we detected an association between the heterozygous T/A genotype and MDS (OR 2.70, 95\% CI 1.81-4.03). However, the $\mathrm{T} / \mathrm{T}$ genotype predicted a shorter survival time in the MDS patients in our study.

To date, only limited number of studies [1-5] documented associations with individual SNPs localized particularly in MTR (5-methyltetrahydrofolate-homocysteine methyltransferase reductase R), RMI1 (RecQ mediated genome instability 1), GSTP1 (glutathione S-transferase pi 1) and $E P O$ (Erythropoietin) genes. However, due to differences in SNPs present on our array that did not include the same polymorphisms as the mentioned studies, we could not confirm these previous results. Recent study of genetic variants of $B L M$ (Bloom syndrome, RecQ helicase-like) gene and the proteins that form complexes with $B L M$, such as TOP3A and RMI1, found the association with cancer risk in acute myeloid leukemia/myelodysplatic syndromes [5]. In our study, we confirmed the association with the $B L M$ gene.

Results obtained from the arrays were validated using another genotyping method - SNPsTaqMan ${ }^{\circledR}$ Assays. The correlation coefficient between both methods was 0.99 , confirming the microarray results. Additionally, the origin of selected polymorphisms (LIG1, RAD52, GPX3) was investigated by comparison of SNP status in paired CD3 monocytes and CD14 T lymphocytes. Genotyping of DNA from separated CD3 and CD14 cells showed the same sequences in both cell lineages, indicating the germline origin of the tested polymorphisms.

\section{Conclusions}

In summary, we identified several genetic variants that may contribute to the pathogenesis of MDS by modifying disease risk. Interestingly, five of the polymorphisms described in our study are located close to areas that are frequently deleted in MDS (chromosome 7 - rs13240966 and rs2235074, chromosome 5 - rs8177426 and rs3797896, and chromosome 20 - rs732417). This observation suggests that in addition to large deletions, other types of genetic alterations in MDS-related regions may play a role in the development of MDS. As discussed above, the genetic variants detected in this study are likely to be biologically relevant, particularly the polymorphisms in oxidative damage/ DNA repair genes (LIG1, RAD52, MSH3 and GPX3), which may play important roles in the pathobiology of MDS. Functional polymorphisms in transmembrane transporters ( $A B C B 1$ and $S L C 4 A 2)$ may contribute to individual variability in drug responses and patient prognoses. Moreover, the variations in the ROS1 and STK6 genes were associated with the overall survival of MDS patients. To our knowledge, this is the first association study to examine the relationships between a large number of SNPs and MDS exclusively in primary MDS patients. Rigorous patient selection is critical because of the differences in etiology observed in primary and secondary MDS, the latter of which is caused by radiation or chemotherapy that is usually administered as a treatment for another type of cancer. Therefore, the incorporation of secondary MDS patients into epidemiological studies could lead to the detection of SNPs related to other types of cancer. This study provides the first evidence of a genetic predisposition to myelodysplasia. However, subsequent genomewide association studies with larger numbers of subjects are needed to confirm our findings, and further elucidation of the relationships between these genetic variants and MDS is required. 


\section{Findings}

Detected genetic variants of DNA repair genes may play important roles in the pathobiology of MDS and polymorphisms in transmembrane transporters may contribute to individual variability in drug responses and patient prognoses.

\section{Additional file}

Additional file 1: Table S1. The list of tested genes.

\section{Competing interests}

The authors declare that they have no competing interests.

\section{Authors' contributions}

$M B$ and $J C$ designed the research protocol; MB, ES and JV performed investigations, analyzed data; DS, DM, RB, RN, AJ and JC were involved in treating patients, collecting data and helped conceive and design the study; $\mathrm{MB}$ and MDM wrote the paper. All authors read and approved the final manuscript.

\section{Acknowledgments}

This work was supported by grant (NT/13899) from the Ministry of Health of the Czech Republic and by the project (Ministry of Health, Czech Republic) for conceptual development of research organization (00023736).

\section{Author details}

${ }^{1}$ Institute of Hematology and Blood Transfusion, U Nemocnice 1, Prague, Czech Republic. ${ }^{2}$ First Faculty of Medicine, Charles University, Prague, Czech Republic. ${ }^{3}$ First Department of Medicine, General University Hospital, Prague, Czech Republic.

Received: 1 November 2012 Accepted: 17 January 2013

Published: 22 January 2013

\section{References}

1. Kim HN, Kim YK, Lee IK, Yang DH, Lee JJ, Shin MH, Park KS, Choi JS, Park MR, Jo DY, Won JH, Kwak JY, Kim HJ: Association between polymorphisms of folate-metabolizing enzymes and hematological malignancies. Leuk Res 2009, 33:82-87.

2. Broberg K, Höglund M, Gustafsson C, Björk J, Ingvar C, Albin M, Olsson H: Genetic variant of the human homologous recombination-associated gene RMI1 (S455N) impacts the risk of AML/MDS and malignant melanoma. Cancer Lett 2007, 258:38-44.

3. Fabiani E, D'Alò F, Scardocci A, Greco M, Di Ruscio A, Criscuolo M, Fianchi L, Pagano L, Hohaus S, Leone G, Voso MT: Polymorphisms of detoxification and DNA repair enzymes in myelodyplastic syndromes. Leuk Res 2009, 33:1068-1071

4. Ma W, Kantarjian H, Zhang K, Zhang X, Wang X, Chen C, Donahue AC, Zhang Z, Yeh CH, O'Brien S, Garcia-Manero G, Caporaso N, Landgren O, Albitar M: Significant association between polymorphism of the erythropoietin gene promoter and myelodysplastic syndrome. BMC Med Genet 2010, 11:163.

5. Broberg K, Huynh E, Schläwicke Engström K, Björk J, Albin M, Ingvar C, Olsson $\mathrm{H}$, Höglund $\mathrm{M}$ : Association between polymorphisms in RMI1, TOP $3 A$, and BLM and risk of cancer, a case-control study. BMC Cancer 2009, 9:140.

6. Vardiman JW, Thiele J, Arber DA, Brunning RD, Borowitz MJ, Porwit A, Harris $\mathrm{NL}$, Le Beau MM, Hellström-Lindberg E, Tefferi A, Bloomfield CD: The 2008 revision of the $\mathrm{WHO}$ classification of myeloid neoplasms and acute leukemia: rationale and important changes. Blood 2009, 114:937-951.

7. Andrew AS, Gui J, Sanderson AC, Mason RA, Morlock EV, Schned AR, Kelsey KT, Marsit CJ, Moore JH, Karagas MR: Bladder cancer SNP panel predicts susceptibility and survival. Hum Genet 2009, 125:527-539.

8. Rao DN, Anuradha C, Vishnupriya S, Sailaja K, Surekha D, Raghunadharao D, Rajappa S: Association of an MDR1 gene (C3435T) polymorphism with acute leukemia in India. Asian Pac J Cancer Prev 2010, 11:1063-1066.
9. Lee YC, Morgenstern H, Greenland S, Tashkin DP, Papp J, Sinsheimer J, Cao W, Hashibe M, You NC, Mao JT, Cozen W, Mack TM, Zhang ZF: A case-control study of the association of the polymorphisms and haplotypes of DNA ligase I with lung and upper-aerodigestive-tract cancers. Int J Cancer 2008, 122:1630-1638.

10. Shin A, Lee KM, Ahn B, Park CG, Noh SK, Park DY, Ahn SH, Yoo KY, Kang D: Genotype-phenotype relationship between DNA repair gene genetic polymorphisms and DNA repair capacity. Asian Pac J Cancer Prev 2008, 9:501-505.

11. Beesley J, Jordan SJ, Spurdle AB, Song H, Ramus SJ, Kjaer SK, Hogdall E, DiCioccio RA, McGuire V, Whittemore AS, Gayther SA, Pharoah PD, Webb PM, Chenevix-Trench G, Australian Ovarian Cancer Study Group, Australian Cancer Study (Ovarian Cancer), Australian Breast Cancer Family Study: Association between single-nucleotide polymorphisms in hormone metabolism and DNA repair genes and epithelial ovarian cancer: results from two Australian studies and an additional validation set. Cancer Epidemiol Biomarkers Prev 2007, 16:2557-2565.

12. Vasikova A, Belickova M, Budinska E, Cermak J: A distinct expression of various gene subsets in CD34+ cells from patients with early and advanced myelodysplastic syndrome. Leuk Res 2010, 34:1566-1572.

13. Ewart-Toland A, Dai Q, Gao YT, Nagase H, Dunlop MG, Farrington SM, Barnetson RA, Anton-Culver H, Peel D, Ziogas A, Lin D, Miao X, Sun T, Ostrander EA, Stanford JL, Langlois M, Chan JM, Yuan J, Harris CC, Bowman ED, Clayman GL, Lippman SM, Lee JJ, Zheng W, Balmain A: Aurora-A/STK15 T+91A is a general low penetrance cancersusceptibility gene: a meta-analysis of multiple cancer types. Carcinogenesis 2005, 26:1368-1373.

14. Matarasso N, Bar-Shira A, Rozovski U, Rosner S, Orr-Urtreger A: Functional analysis of the Aurora Kinase A lle31 allelic variant in human prostate. Neoplasia 2007, 9:707-715.

15. Grosjean-Raillard J, Adès L, Boehrer S, Tailler M, Fabre C, Braun T, De Botton $\mathrm{S}$, Israel A, Fenaux P, Kroemer G: Flt3 receptor inhibition reduces constitutive NFkappaB activation in high-risk myelodysplastic syndrome and acute myeloid leukemia. Apoptosis 2008, 13:1148-1161.

16. Davies S, Dai D, Feldman I, Pickett G, Leslie KK: Identification of a novel mechanism of NF-kappaB inactivation by progesterone through progesterone receptors in $\mathrm{Hec} 50 \mathrm{co}$ poorly differentiated endometrial cancer cells: induction of A20 and ABIN-2. Gynecol Oncol 2004, 94:463-470.

doi:10.1186/1756-8722-6-9

Cite this article as: Belickova et al.: DNA repair gene variants are associated with an increased risk of myelodysplastic syndromes in a Czech population. Journal of Hematology \& Oncology 2013 6:9.

\section{Submit your next manuscript to BioMed Central and take full advantage of:}

- Convenient online submission

- Thorough peer review

- No space constraints or color figure charges

- Immediate publication on acceptance

- Inclusion in PubMed, CAS, Scopus and Google Scholar

- Research which is freely available for redistribution 